\title{
A tranexámsav vérvesztést és kis vérzéses szövődményeket befolyásoló hatása cementes csípőprotézis beültetése után
}

\author{
Gombár Csaba dr. ${ }^{1}$ - Gálity Hristifor dr. ${ }^{1}$ \\ Bácsi Miklós dr. ${ }^{2}$ - Sisák Krisztián dr. ${ }^{1}$ \\ 'Szegedi Tudományegyetem, Általános Orvostudományi Kar, Szent-Györgyi Albert Klinikai Központ, \\ Ortopédiai Klinika, Szeged \\ ${ }^{2}$ Bács-Kiskun Megyei Kórház, Ortopédiai Osztály, Kecskemét
}

\begin{abstract}
Bevezetés: A tranexámsav (TXA) napjainkban rutinszerúen használt gyógyszer elektív ízületi protetizálás esetében, a műtét során kialakuló vérveszteség, illetve transzfúziós igény csökkentése céljából.

Célkitüzés: A dolgozat célja, hogy értékelje a tranexámsav kis vérzési szövődményekre kifejtett hatását cementes csípőprotézis beültetése során, amikor rivaroxabant használunk antikoagulánsként, melynél az elmúlt időszakban több vizsgálat is nagyobb arányban előforduló sebgyógyulási zavart igazolt.

Módszer: Retrospektív módon vizsgáltuk a csípőprotézis-beültetésen átesett betegeket. Azok a betegek, akiket 2014. január és november között perioperatív tranexámsavval kezeltek, a TXA-csoportba kerültek. Ezt a csoportot a 2012 februárja és decembere között, a tranexámsav bevezetése előtt hasonló beavatkozáson átesett betegek adataival hasonlítottuk össze (kontrollcsoport). Vizsgáltuk a tranexámsavnak a mútéti seb vérzésére és váladékozására, a seb körül látható bőrfelszíni haematoma méretére, a combtérfogat-változásra és a számított perioperatív vérveszteségre kifejtett hatását.

Eredmények: Összesen 168 beteget vontunk be a vizsgálatunkba, 81 beteget a TXA-csoportba és 87 beteget a kontrollcsoportba. A posztoperatív combtérfogat-növekedés kisebb mértékú, mindössze $270,3 \mathrm{ml}(129,1-449)$ volt a TXA-csoportban, míg 539,8 ml (350-864,8) a kontrollcsoportban ( p<0,001). A számított perioperatív vérveszteség kisebb volt a TXA-csoportban (1150 ml [780-1496]), mint a másik csoportban (1579 ml [1313-2074]) $(\mathrm{p}<0,001)$. A tranexámsavval kezelteknél a transzfúziós igény több mint a felére csökkent, itt a betegek 15\%-a, míg a kontrollcsoportban a $39 \%$-uk kapott vért.

Következtetések: A tranexámsav csökkentette a posztoperatív combtérfogat-növekedés, a mútéti sebvérzés és a bőrfelszínen látható haematoma mértékét akkor is, amikor rivaroxabant használtunk antikoagulánsként. További nagy esetszámú kutatások szükségesek, hogy vizsgálják a tranexámsavnak a kis vérzési szövődményekre és azok potenciális szövődményeire (posztoperatív fertőzés) kifejtett hosszú távú hatását.
\end{abstract}

Orv Hetil. 2019; 160(12): 456-463.

Kulcsszavak: teljes csípőprotézis, vérzés, rivaroxaban, tranexámsav, vénás thrombosis

\section{Effect of tranexamic acid on blood loss and soft-tissue swelling following cemented total hip replacement}

Introduction: Tranexamic acid (TXA) is widely used during elective joint replacement to reduce blood loss and decrease the transfusion requirement.

Aim: This study assessed the efficacy of tranexamic acid in reducing minor bleeding complications following primary cemented total hip replacement, when rivaroxaban is used as thromboprophylaxis, the complicated wound healing effect of which has been published recently.

Method: Consecutive patients undergoing hip replacement were studied. Patients receiving tranexamic acid perioperatively between January 2014 and November 2014 were designated as the TXA-group. We compared these data with those of a group of patients who underwent the same procedure between February 2012 and December 2012 (control group), before the introduction of tranexamic acid. The authors investigated the effect of tranexamic acid on surgical wound bleeding and discharge, area of hematoma on the skin surface, thigh volume changes, calculated perioperative blood loss and transfusion requirement. 
Results: 168 patients, 81 in the TXA-group and 87 in the control group were included. The extent of postoperative thigh swelling was significantly less in the TXA-group, $270.3 \mathrm{~mL}(129.1-449.0)$ as compared with the control group, $539.8 \mathrm{~mL}(350.0-864.8, \mathrm{p}<0.001)$. Tranexamic acid significantly reduced wound bleeding during the first 24 hours postoperatively $(\mathrm{p}<0.001)$. The amount of calculated blood loss was significantly less in the TXA-group (1150 mL [780-1496] versus $1579 \mathrm{~mL}$ [1313-2074] in the control group, $\mathrm{p}<0.001)$. Transfusion requirement was remarkably lower in the TXA-group than in the control group ( $15 \%$ versus $39 \%$ ).

Conclusions: Tranexamic acid reduces postoperative thigh volume, wound bleeding and area of hematoma on the skin surface when rivaroxaban is used as the anticoagulant. Further large scale studies could help establish the clinical relevance and long-term outcome of minor bleeding complications.

Keywords: total hip replacement, hemorrhage, rivaroxaban, tranexamic acid, venous thrombosis

Gombár Cs, Gálity H, Bácsi M, Sisák K. [Effect of tranexamic acid on blood loss and soft-tissue swelling following cemented total hip replacement]. Orv Hetil. 2019; 160(12): 456-463.

(Beérkezett: 2018. október 12.; elfogadva: 2018. november 19.)

\begin{abstract}
Rövidítések
ÁOK = Általános Orvostudományi Kar; aPTT = (activated partial thromboplastin time) aktivált parciális tromboplasztinidő; $\mathrm{CI}=($ confidence interval $)$ konfidenciaintervallum; $\mathrm{CT}=(\mathrm{com}-$ puted tomography) számítógépes tomográfia; $\mathrm{Hb}=$ hemoglobin; Hct $=$ hematokrit; INR = (international normalized ratio $)$ nemzetközi normalizált hányados; iv. = intravénás; $\mathrm{LMWH}=$ (low molecular weight heparin) kis molekulatömegü heparin; MVT $=$ mélyvénás thrombosis; NSAID $=($ non-steroidal antiinflammatory drug) nemszteroid gyulladáscsökkentő; PBV = (patient's blood volume) a beteg teljes vértérfogata; $\mathrm{PE}=$ pulmonalis embolia; $\mathrm{PT}=$ (prothrombin time) protrombinido"; $\mathrm{SD}=$ standard deviáció; $\mathrm{SEM}=($ standard error of the mean $) \mathrm{a}$ középérték közepes hibája; SZTE = Szegedi Tudományegyetem; $\mathrm{TEP}=$ teljes endoprotézis; $\mathrm{TXA}=$ tranexámsav; vvt. = vörösvértest
\end{abstract}

Magyarországon évente körülbelül tízezer csípóízületi teljes endoprotézis (csípö-TEP) beültetése történik. A beavatkozás során és a közvetlen posztoperatív időszakban a legalaposabb vérzéscsillapítás esetén is akár több mint 1 liter vérveszteség előfordulhat. Ezt az idősebb, társbetegségektől is szenvedő betegek nehezen tolerálják, ami a posztoperatív rehabilitáció és a kórházban töltött idő megnyúlását okozhatja [1]. A perioperatív vérveszteség mértéke transzfúziót is szükségessé tehet, a publikált adatok szerint ez az igény akár a betegek $60 \%$-át érintheti. Mind az autológ, mind az allogén vér transzfúziója jelentősen emeli a költségeket, a vérrel terjedő betegségek és transzfúziós szövődmények kockázatát, illetve a protézisbeültetést követő infekció előfordulási gyakoriságát. Számos módszer létezik a magas transzfúziós igény csökkentésére, ilyenek például a különböző vérmentô technikák (cell-saver), kontrollált hipotenzió és hemodilúció a mútét közben, epoetin-alfával végzett erythropoesisstimuláció, a restriktív (csak nagyon alacsony hemoglobinérték [70 g/l] melletti) transzfúzió, illetve a fibrinolízist gátló hatóanyagok alkalmazása (például tranexámsav, aprotinin, $\varepsilon$-aminokapronsav stb.), amelyek csökkenthetik a mútét közbeni és az azt követő vérveszteséget.

A tranexámsav (TXA) egy költséghatékony fibrinolízist gátló szer, mely elektív általános és ortopédiai sebészetben is csökkenti a vérveszteséget $[2,3] .2013$ őszén került törzskönyvezésre Magyarországon térd- és csípőTEP-beültetés indikációjával, rövid idő alatt az ortopédiai mútétek perioperatív protokolljainak meghatározó részévé vált. A TXA hatékonyságát és biztonságát $[4,5]$, az optimális alkalmazás módját, idôpontját és dózisát számos kutatás bizonyította [2, 3, 6, 7]. Kevés adatunk van az elmúlt években széles körben elterjedt, új, szájon át szedhető, perioperatív antikoagulánsként használt rivaroxaban és a TXA kombinált alkalmazásáról cementes csípő-TEP beültetésén átesett betegek esetében $[8,9]$. A TXA hatásait vizsgáló legtöbb tanulmány középpontjában a perioperatív vérveszteség állt, azonban a sebészi szempontból talán legfontosabb kis vérzési szövődményekre, mint például a sebváladékozásra, seb körüli haematoma képződésére, seroma kialakulására kifejtett hatásának megfigyelése eddig háttérbe szorult. Az elhúzódó posztoperatív sebváladékozás és fokozott mértékú haematomaképződés nemcsak a kórházban töltött napok számát növeli, hanem befolyásolhatja a korai mobilizációt, és fokozhatja a protézisbeültetést követő fertőzés arányát is. Célunk volt megfigyelni a TXA posztoperatív vérveszteségre kifejtett hatását, amikor véralvadásgátlóként rivaroxabant használunk, továbbá kifejezett figyelmet fordítottunk a sebgyógyulást is befolyásoló kis vérzési szövődmények előfordulási gyakoriságára.

\section{Módszer}

A vizsgálatban két csoport vett részt: 1) TXA-csoport: 2014. január és november között cementes csípó-TEP beültetésén átesett betegek, akik perioperatívan tranexámsavkezelésben részesültek. Az érvényben lévő ajánlásokat figyelembe véve alkalmaztunk $500 \mathrm{mg}$ TXA-at intravénásan (iv.) a bemetszés előtt, és azt 3 órával később 
megismételtük. 2) A kontrollcsoportot mindenben azonos módon kezelt olyan betegek alkották, akik 2012. február és december között cementes csípő-TEP beültetésében részesültek, még a tranexámsav bevezetése előtt. Mindkét vizsgálati periódusban olyan betegeket vontunk be, akik esetében arthrosis vagy avascularis combfejnecrosis miatt primer cementes csípóprotézis beültetése történt, és perioperatív véralvadásgátlóként rivaroxabant (Xarelto ${ }^{\circledR}$, Bayer Schering Pharma, Berlin, Németország) alkalmaztunk. A rivaroxaban adagolása a jelenleg is érvényben lévő ortopédiai szakmai ajánlásnak és gyártói előírásoknak megfelelően történt: mütét után 6 órával kezdtük az adagolást, majd a betegek naponta egyszer, este nyolc órakor kapták a mútétet követő 28-35 napig $[10,11]$. A regionális kutatásetikai bizottság jóváhagyta a vizsgálatot, minden résztvevőtől írásos beleegyezést kértünk.

A nemszteroid gyulladáscsökkentő szerek (non-steroidal anti-inflammatory drug, NSAID) és az acetilszalicilsav adagolását egy héttel a mútét időpontja előtt leállítottuk. A mútét előtt ellenőriztük a vese- és májfunkciós laborértékeket, az aktivált parciális tromboplasztinidőt (activated partial thromboplastin time, aPTT), protrombinidőt (prothrombin time, PT) és a nemzetközi normalizált hányadost (international normalized ratio, INR). Vizsgálatunkba nem vontuk be azokat a betegeket, akik csípőízületi protézis revíziós mútétén estek át, akiknek vese- és/vagy májfunkciós zavaruk, véralvadási zavaruk volt, valamint az állandóan antikoaguláns terápiára szorulókat (például acenokumarol, warfarin, klopidogrél), továbbá az ismert epilepsziás betegeket, vagy akiknek ismert allergiájuk volt a tranexámsavval és/vagy rivaroxabannal szemben.

A mútéti beavatkozásokat általános vagy regionális vagy a kettőt kombináló anesztézia alatt végeztük, attól függően, hogy az aneszteziológus melyiket tartotta az adott beteg esetében a legmegfelelőbbnek. A mútéteket összesen hét, ugyanabban az ortopédiai intézetben dolgozó ortopéd sebész végezte el, direkt lateralis (Bauerféle) feltárásból. Minden beteg cementes csípő-TEP-t kapott. A mútétek során és a korai posztoperatív időszakban nem használtunk cell-savert vagy egyéb, újra transzfundálható vérgyűjtő rendszert. A mütéteket antibiotikumos védelemben végeztük, cefuroximot vagy penicillinallergia esetén klindamicint használtunk. A mütét alatti vérveszteség mennyiségét szívókészülék gyưjtőtartályából számítottuk ki, levonva abból a mútét alatt pontosan rögzített öblítőfolyadék mennyiségét. A mütéti területet egy darab szívódrén felett zártuk, melyet a mútét után legkésőbb 24 órával távolítottunk el; a drénváladékot milliliterbeosztással rendelkező Redon ${ }^{\circledR}$ palackokban gyüjtöttük. A dréncső eltávolítása után a műtéti sebet és a szívócsövek kilépési helyét Mepore ${ }^{\circledR}$ típusú kötszerrel fedtük.

Szükség szerinti fájdalomcsillapítóként paracetamolt, tramadolt és metamizolt adtunk. A gyógytornát az első mútét utáni napon kezdtük, addukciót és kirotációt tiltva, teljes testsúlyterheléssel a mútött végtagon.

A mútét utáni mélyvénás thrombosisra (MVT) utaló tünetek megfigyelése nem volt a vizsgálatunk része, azonban klinikai gyanú vagy igazolt események a műtét utáni hatodik hétig feljegyzésre kerültek. Alsó végtagi fájdalom, duzzanat, jelentős ödéma, livid elszíneződés, pozitív Meyer- és Homans-tünet fennállásakor színkódolt Doppler-ultrahangos vizsgálatot végeztünk a MVT kizárására. Pulmonalis embolia (PE) gyanúja (légszomj, nem szûnő köhögési inger, vérköpés, mellkasi fájdalom stb.) esetén az intézeti protokoll szerint, a mellkas CTvizsgálatát végeztük el.

Vizsgálatunk során a kis vérzési szövődményeket vizsgáltuk, melyeken a mútéti sebvonalon keresztüli vérzést és váladékozást, a mütéti seb körül a bőrfelszínen látható haematomát (suffusio) és a perioperatív combtérfogatnövekedést értettük.

\section{Sebvérzés és serosus sebváladékozás}

A sebvérzés definíciója a megfigyelés során a mútéti seb vérzése a fedőkötésbe a posztoperatív első 24 órában, egészen a dréncsövek eltávolításáig. Intenzitásának értékelését az 1. táblázatban látható, általunk meghatározott kategóriák szerint végeztük. Seroma kialakulásának tekintettük a csövek eltávolítása után a mútéti sebnek és a dréncsövek kilépési helyének a serosus váladékozását. A seroma megszünésének napját pontosan feljegyeztük. A mütét utáni hetedik napon a seb körüli haematoma (suffusio) kiterjedését a seb körül (akár az egész operált végtagra terjedően) a bőr felszínén megbecsültük, majd ez alapján a 2. táblázatban látható, általunk meghatározott kategóriákba soroltuk a betegeket.

\begin{tabular}{ll} 
1. táblázat & | Sebvérzés (mútét utáni 0-24 óráig, a dréncsövek eltávolításáig) \\
\hline 0. & Tiszta és száraz fedőkötés \\
1. & Kis foltok a fedőkötésen \\
2. & $\begin{array}{l}\text { Egy nap alatt a fedőkötés csak egy része nedvesedik át, } \\
\text { naponta egyszer kötéscsere }\end{array}$ \\
3. & $\begin{array}{l}\text { A teljes fedőkötés átnedvesedik egy nap alatt, naponta } \\
\text { többször kötéscsere és/vagy kiegészítő fedőlapok } \\
\text { felhelyezése szülkséges }\end{array}$ \\
\hline
\end{tabular}

2. táblázat |A haematoma mérete szerinti kategóriák

\begin{tabular}{ll}
\hline 0. & Nincs \\
1. & $<100 \mathrm{~cm}^{2}$ \\
2. & $100-200 \mathrm{~cm}^{2}$ \\
3. & $200-300 \mathrm{~cm}^{2}$ \\
4. & $300-400 \mathrm{~cm}^{2}$ \\
5. & $400-500 \mathrm{~cm}^{2}$ \\
6. & $500 \mathrm{~cm}^{2}<$ \\
\hline
\end{tabular}




\section{A combtérfogat változása}

Csípő-TEP-beültetés után a fokozott váladéktermelődés nemcsak serosus sebváladékozás formájában jelentkezhet, hanem a lágyrészek között felhalmozódva, akár a combtérfogat növekedésével is együtt járhat [12]. A Jones és Pearson által kifejlesztett antropometriai módszer az alsó végtagot hat csonka gúlára osztja fel, így pontosan kiszámítható annak térfogata [13]. A combtérfogat kiszámolásához a legfelső három csonka gúla adatai elegendőek. Mútét előtt és a mútét utáni hetedik napon a combot lemérve, könnyen kiszámítható a posztoperatív térfogatváltozás. A beteg egyenesen áll, vállszélességnyi terpeszben, a lábfejek egymással párhuzamosan. Négy körfogatot mérünk le előre meghatározott magasságokban: 1) a fenékredő magasságában, 2) a térdízületi ízrés és a fenékredő közti távolság egyharmadnyi magasságában, 3) a térdízület feletti legkisebb körfogat, 4) a térdízület körüli legnagyobb körfogat. A csonka gúlák magasságait (azaz a körfogatok közti magasságokat) testmagasságmérővel (stadiométerrel) határoztuk meg. Ezután kiszámítottuk a három csonka gúla térfogatát, majd azokat összeadva megkaptuk a combtérfogatot.

\section{A teljes perioperatív vérveszteség számítása}

A műtét előtt, a műtét utáni első, második és ötödik napon ellenőriztük a hematokrit (Hct) és a hemoglobin (Hb) szintjét. Feltételeztük, hogy a vértérfogat és a hemodilúció a mütét utáni ötödik napra rendeződik, így a teljes perioperatív vérveszteséget a mütét előtti és a mütét utáni ötödik napon mért hematokritkülönbségből számítottuk. A beteg teljes vértérfogatát (patient's blood volume - PBV) a Nadler-Hidalgo-Bloch-egyenlet [14] segítségével számítottuk ki:

$\operatorname{PBV}($ liter $)=$

$\left(k 1 \times\right.$ magasság $\left.^{3}[m]\right)+(k 2 \times$ testtömeg $[k g])+k 3$,

ahol a $k 1=0,3669, k 2=0,03219$ és $k 3=0,6041$ a férfiaknál, és $k 1=0,3561, k 2=0,03308$ és $k 3=0,1833$ a nőknél.

Ha a PBV-t megszorozzuk a hematokritértékkel, akkor megkapjuk a vörösvértest (vvt.)-térfogatot. Így a vvt.-térfogat-változást kiszámíthatjuk a hematokritszint változásából [15]:

Teljes vvt.-térfogat-csökkenés = $\mathrm{PBV} \times\left(\mathrm{Hct}_{\text {pre-op }}-\mathrm{Hct}_{\text {post-op }}\right)$

A kórházi bennfekvés alatt feljegyzésre került a transzfundált vvt.-egységek száma. Egy transzfundált egység átlagos térfogata $280 \mathrm{ml}$, míg átlagos hematokritértéke 0,55 . Ezeket az adatokat ismerve a transzfúzió térfogatát is beleszámítottuk a teljes vérveszteségbe:
Teljes vérveszteség (liter) =

[teljes vvt.-térfogat-csökkenés + (beadott vvt.-egységek száma $\times 0,28 \times 0,55)] /\left[\left(\mathrm{Hct}_{\text {pre-op }}+\mathrm{Hct}_{\text {post-op }}\right) / 2\right]$

\section{Statisztika}

A két csoport adatait egy későbbi időpontban, retrospektív módon hasonlítottuk össze. A statisztikai számításokhoz az SPSS 16.0 szoftvert (SPSS Inc., Chicago, IL, Egyesült Államok) használtuk. Az adatok normalitását Shapiro-Wilk-teszttel vizsgáltuk. A parametrikus értékek esetében Student-féle t-próbát, a nemparametrikus értékeknél pedig Mann-Whitney-próbát alkalmaztunk. A kategorikus változók értékeléséhez a khi-négyzet-próbát, illetve a Fisher-féle egzakt próbát használtuk, ha szükség volt rá. Az eredmények és az adatok a dolgozatban mint átlag ( \pm standard deviáció $[\mathrm{SD}]$ ) vagy mint medián érték (interkvartilis tartomány) lettek feltüntetve. A különbségeket szignifikánsnak tekintettük, ha a p-érték kisebb volt, mint 0,05 .

\section{Eredmények}

A korábban leírt kritériumok alapján a TXA-csoportba 81 beteg, a kontrollcsoportba pedig 87 beteg került. A két csoportot leíró adatok a 3. táblázatban láthatók. Ezek alapján a két csoport hasonló, statisztikailag azonosnak tekinthetők. Három betegnél alakultak ki MVTra utaló klinikai tünetek a kórházi benntartózkodás alatt,

3. táblázat | A betegeket leíró adatok \pm SD (min.-max.)

\begin{tabular}{|c|c|c|c|}
\hline & TXA-csoport & Kontrollcsoport & p-érték \\
\hline A betegek száma & 81 & 87 & \\
\hline A nemek aránya & $18 \hat{\delta} / 63+$ & $21 \delta / 66+$ & \\
\hline Átlagéletkor & $\begin{array}{l}68 \pm 6,7 \\
(46-81)\end{array}$ & $\begin{array}{l}69 \pm 8,2 \\
(49-85)\end{array}$ & 0,798 \\
\hline Magasság $(\mathrm{cm})$ & $\begin{array}{c}163 \pm 9,1 \\
(140-195)\end{array}$ & $\begin{array}{c}163 \pm 7,9 \\
(148-180)\end{array}$ & 0,815 \\
\hline Testtömeg (kg) & $\begin{array}{c}76,2 \pm 12,4 \\
(45-100) \\
\end{array}$ & $\begin{array}{c}74,5 \pm 11,5 \\
(54-100) \\
\end{array}$ & 0,339 \\
\hline BMI $\left(\mathrm{kg} / \mathrm{m}^{2}\right)$ & $\begin{array}{c}28,5 \pm 3,8 \\
(19,9-36,4) \\
\end{array}$ & $\begin{array}{c}28 \pm 3,7 \\
(21,6-38,5)\end{array}$ & 0,213 \\
\hline $\begin{array}{l}\text { Mútét elötti } \\
\text { combkörfogat }(\mathrm{ml})\end{array}$ & $\begin{array}{l}5194 \pm 1129 \\
(3153-7588)\end{array}$ & $\begin{array}{l}4868 \pm 1002 \\
(2882-8210)\end{array}$ & 0,082 \\
\hline $\begin{array}{l}\text { A betegek } \\
\text { vértérfogata (1) }\end{array}$ & $\begin{array}{l}4,411 \pm 0,711 \\
(2540-6210) \\
\end{array}$ & $\begin{array}{l}4,353 \pm 0,66 \\
(3260-5800) \\
\end{array}$ & 0,54 \\
\hline $\begin{array}{l}\text { Mútét előtti } \\
\text { hematokrit }\end{array}$ & $\begin{array}{c}0,40 \pm 0,038 \\
(0,30-0,50) \\
\end{array}$ & $\begin{array}{l}0,41 \pm 0,04 \\
(0,30-0,48)\end{array}$ & \\
\hline $\begin{array}{l}\text { A mútét időtartama } \\
\text { (perc) }\end{array}$ & $\begin{array}{l}75 \pm 20,9 \\
(30-130)\end{array}$ & $\begin{array}{c}77 \pm 17 \\
(42-150)\end{array}$ & 0,238 \\
\hline $\begin{array}{l}\text { Az anesztézia típusa: } \\
\text { általános/regionális/ } \\
\text { kombinált }\end{array}$ & $13 / 56 / 12$ & $16 / 61 / 10$ & \\
\hline
\end{tabular}

$\mathrm{BMI}=$ testtömegindex; $\mathrm{TXA}=$ tranexámsav 


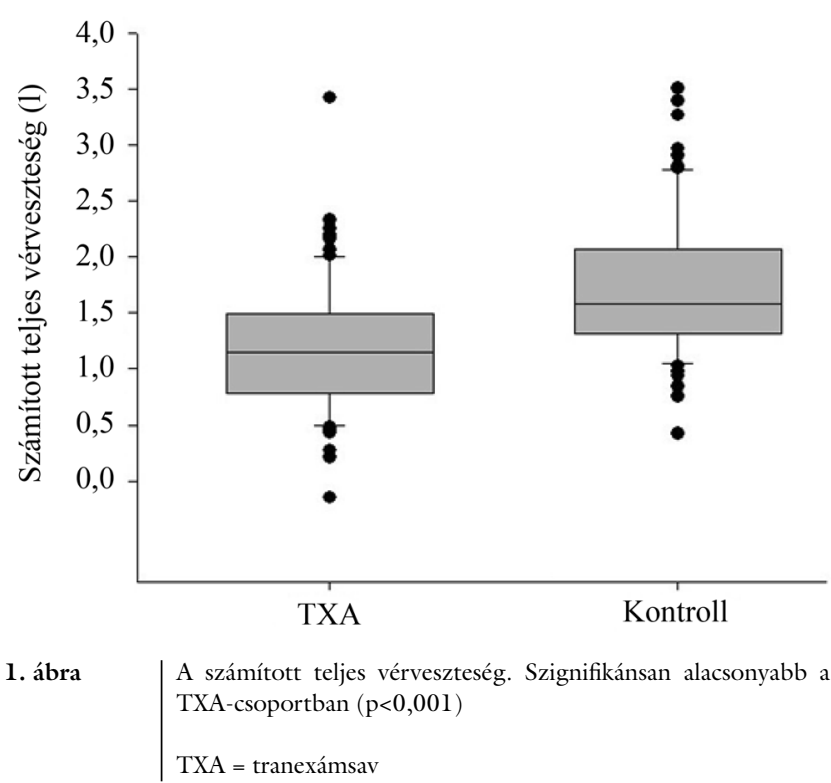

azonban színes-Doppler-ultrahangvizsgálat ezt nem igazolta. Vénás thromboembolia vagy halált okozó szövődmény nem történt a vizsgálat alatt és a posztoperatív 6 hét alatt. Nem volt szignifikáns különbség a két csoport között a mütét alatti vérveszteség mennyiségében: 306 $\mathrm{ml}( \pm 127 \mathrm{ml})$ volt a TXA-csoportban és $317 \mathrm{ml}( \pm 171$ $\mathrm{ml})$ a kontrollcsoportban $(\mathrm{p}=0,957)$. A mütét utáni drénváladék mennyisége szignifikánsan kevesebb, 280 $\mathrm{ml}(170-350 \mathrm{ml})$ volt a TXA-csoportban, míg $400 \mathrm{ml}$ $(300-550 \mathrm{ml})$ volt a kontrollcsoportban $(\mathrm{p}<0,001)$. A számított perioperatív vérveszteség szignifikánsan kevesebb, $1150 \mathrm{ml}$ (780-1496 ml) volt a TXA-csoportban, összehasonlítva a kontrollcsoport 1579 ml (1313-2074 $\mathrm{ml}$ ) értékeivel $(\mathrm{p}<0,001)$ (1. ábra). Mütét után a TXAcsoportban 12 (15\%) betegnek volt szüksége transzfúzióra, míg a kontrollcsoportban 34 (39\%) betegnek. Összesen 26 egység vvt.-koncentrátumot kaptak a TXAcsoportban a betegek, szemben a kontrollcsoportban összesen felhasznált 82 egységgel. Az átlagos transzfúziós igény szignifikánsan kisebb volt azon betegek között, akik perioperatívan tranexámsavat kaptak $(0,32$ egység $[ \pm 0,09$ egység $]$, szemben a 0,94 egységgel $[ \pm 0,15$ egység], $\mathrm{p}=0,003)$. A posztoperatív első 24 órában a müté-

\begin{tabular}{|c|c|c|}
\hline 4. táblázat & \multicolumn{2}{|c|}{$\begin{array}{l}\text { A sebvérzés intenzitásának, gyakoriságának bemutatása. A seb- } \\
\text { vérzés intenzitása a mútét utáni } 24 \text { órában szignifikánsan alacso- } \\
\text { nyabb volt a TXA-csoportban }(\mathrm{p}<0,001) \text { a kontrollcsoporthoz } \\
\text { képest. Az adatok mint abszolút (relatív \%) gyakoriság lettek } \\
\text { bemutatva. A kategóriák magyarázata az 1. táblázatban látható }\end{array}$} \\
\hline Kategória & $\begin{array}{l}\text { TXA-csoport } \\
(\mathrm{n}=81)\end{array}$ & $\begin{array}{l}\text { Kontrollcsoport } \\
\qquad(\mathrm{n}=87)\end{array}$ \\
\hline 0. & $64(79,0 \%)$ & $1(1,1 \%)$ \\
\hline 1. & $10(12,3 \%)$ & $39(44,8 \%)$ \\
\hline 2. & $3(3,7 \%)$ & $31(35,6 \%)$ \\
\hline 3. & $4(4,9 \%)$ & $16(18,4 \%)$ \\
\hline
\end{tabular}

TXA = tranexámsav

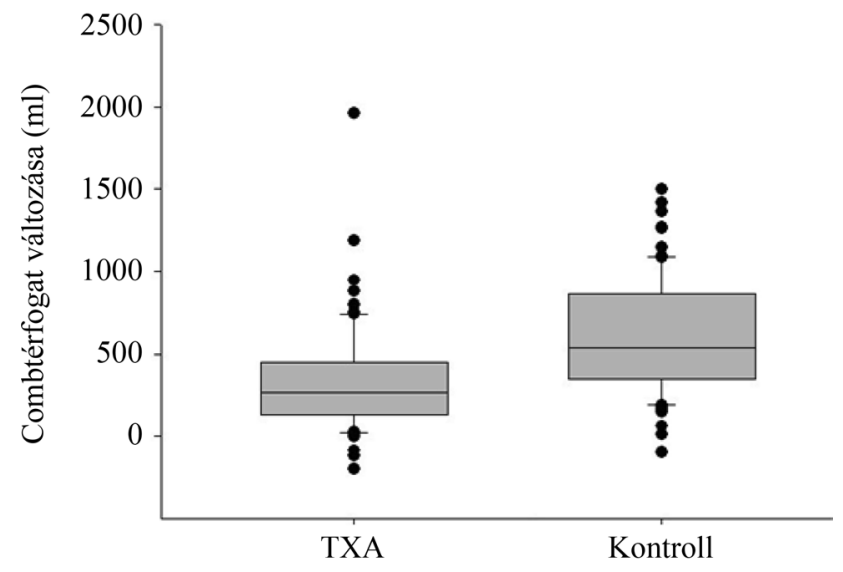

2. ábra

A combtérfogat változása mútét után. Szignifikánsan nagyobb térfogat-növekedés volt a kontrollcsoportban a mútét utáni 7 . napon $(\mathrm{p}<0,001)$

TXA $=$ tranexámsav

ti seb vérzése szignifikánsan különbözött a két csoportban: 1,71 (SEM $\pm 0,083)$ a kontrollcsoportban, szemben a TXA-csoport értékével: 0,35 (SEM $\pm 0,086)$. Az egyes sebvérzési kategóriákban előforduló esetek száma a 4 . táblázatban látható. A serosus sebváladékozás időtartama a drén eltávolítása után rövidebb ideig tartott a TXAcsoportban $(0,6$ nap $[ \pm 0,1$ nap $])$, összehasonlítva a kontrollcsoporttal (1,2 nap [ \pm 1,9 nap]), ez azonban statisztikailag nem mutatott szignifikáns különbséget $(\mathrm{p}=0,064)$. A combtérfogat-növekedés mértéke szignifikánsan különbözött a mütét utáni hetedik napon a két csoportban: 270,3 ml (129-449 ml) a TXA-csoportban és 539,8 $\mathrm{ml}(350-865 \mathrm{ml})$ a kontrollcsoportban $(\mathrm{p}<0,001)$ (2. ábra). A haematoma mérete a mútét utáni hetedik napon szignifikánsan kisebb volt a TXA-csoportban $(0,6[ \pm 0,2]$ versus $2,5[ \pm 2,1])(\mathrm{p}<0,001)$.

\section{Megbeszélés}

Az elmúlt évtizedben számos vizsgálat bizonyította a tranexámsav (TXA) olcsó és eredményes, fibrinolízist gátló hatását, mely elektív általános és ortopédiai sebészetben is csökkenti a vérveszteséget $[2,3]$.

Egy metaanalízisvizsgálatban azt találták, hogy különböző sebészi szakterületek (szívsebészet, ortopédia, szülészet és nőgyógyászat, fej- és nyaksebészet, májsebészet és urológia) mütéti beavatkozásai során széles dózishatárok között (5,5-300 mg/tskg) alkalmazzák a TXA-at. A TXA hatékonyságát összegezve, az alkalmazott dózis mennyisége és az arra adott vérveszteség-csökkentő reakció között nem arányos a kapcsolat. Ez alapján azt az általános következtetést vonták le, hogy a mútét körüli időszakban alkalmazott összesen $1 \mathrm{~g}$ TXA, vagy körülbelül $14 \mathrm{mg} /$ tskg TXA, a legtöbb felnőtt esetében megfelelő hatást biztosít [16].

A tranexámsav alkalmazása az alsó végtagi mútétek perioperatív protokolljainak meghatározó részévé vált az 
elmúlt évek során. A szer hatékonyságát, alkalmazási időpontját és dózisát számos kutatás bizonyította [2-7]. $\mathrm{Az}$ alkalmazási útvonalat (lokális infiltrációs, szisztémás parenterális vagy per os) napjainkban is gyakran vizsgálják. Az eddigi ortopédiai vizsgálatok alapján elmondható, hogy az ízületiprotézis-beültetés esetében a perioperatív időszakban, iv. alkalmazott összesen $1 \mathrm{~g}$ TXA és a 10-20 mg/tskg dózisban adott TXA is hatásosan csökkenti a vérveszteséget és a transzfúziós igényt [16-19]. Az alkalmazás időzítését tekintve a csípőprotézis-beültetés esetében iv. alkalmazott TXA-at 10 perccel a bemetszés előtt ajánlott adni, majd a mútét után 3-6 órával megismételni a dózist. Ekkor csökken a legnagyobb arányban a számított vérveszteség, a drénváladék menynyisége a mütét utáni első napon, az összességében mért hemoglobinesés mértéke és a posztoperatív vérveszteség [20].

Jelenleg a TXA ortopédiai alkalmazásával kapcsolatos vizsgálatok középpontjában a helyi alkalmazási mód áll. A seb zárása előtt $250 \mathrm{mg}-3 \mathrm{~g}$ TXA-at adnak az ízület körüli szövetekbe, esetleg egyéb fájdalomcsillapítókkal keverve infiltrálják a mütéti területet (ízületi tok a környező lágyrésszel) a lokális infiltrációs anesztézia részeként [21]. E módszer előnye az egyszerúbb beadás, és a hatóanyag a mútéti környezetben, az ízületben, azaz a vérzés helyén van jelen a legnagyobb terápiás koncentrációban. Vizsgálatok szerint ilyenkor a szisztémás koncentráció minimális, így a mellékhatások miatti aggodalom is csökken [22].

Magyarországon 2013 őszén törzskönyvezték a tranexámsav használatát csípő- és térd-TEP-beültetés mütéti indikációjával, mely szerint a következő alkalmazási módszerei javasoltak: helyi fibrinolízis kezelésére napi 0,5-1 g tranexámsav lassú, iv. injekció formájában, két vagy három részre elosztva, míg generalizált fibrinolízis esetén $1 \mathrm{~g}$ tranexámsav lassú, iv. injekció formájában 6 vagy 8 óránként $15 \mathrm{mg}$ /testsúlykilogrammnak megfelelően (pharmindex-online.hu). Vizsgálatunkban az érvényben lévő ajánlásokat és a korábbi kutatások eredményeit figyelembe véve alkalmaztunk $500 \mathrm{mg}$ tranexámsavat intravénásan a bemetszés előtt és azt 3 órával később megismételtük.

Számos ortopédiai tanulmány vizsgálta már a tranexámsav számított és mért perioperatív vérveszteségcsökkentő hatását, azonban kis esetszámok és a több változó együtt elemzése (például cementes/cement nélküli csípőprotézis, különböző perioperatív antikoaguláns, eltérő alkalmazási idő és mód) miatt csak kevés vizsgálat adott jelentős fajsúlyú konklúziót.

A cementes csípő-TEP esetében a cement lezárja a femoralis csatornát és az acetabularis csontos ágyat, így az nyomás révén csökkenti a vérzést az intramedullaris keringés felől. Ezt figyelembe véve, indokolt a cementes és a cement nélküli rögzülésű protézisek esetében külön vizsgálni a perioperatív vérveszteség mértékét, illetve a tranexámsavnak a vérveszteségre kifejtett hatását is [23]. Eddig kevés tanulmány vizsgálta a TXA kis vérzési szö- vődményeket és a sebgyógyulást befolyásoló hatását [2, $3,9,24$ ] és még kevesebb a TXA hatását rivaroxabannal kombinálva tisztán csak cementes, vagy csak cement nélküli csípő-TEP beültetésén átesett betegcsoportban [8].

A rivaroxaban szájon át szedhető, direkt hatású, szelektív Xa-inhibitor. Klinikai hatékonyságát a MVT-ok és PE-k megelőzésében nagyízületi protézisbeültetések után igazolták [25]. Hatását a thrombosismegelőzésben régóta bázisszernek számító kis molekulatömegű heparinnal (LMWH), a bőr alá injekciós formában adható enoxaparinnal hasonlították össze. Bizonyított, hogy hasonló hatékonysággal előzi meg a vénás thromboemboliás szövődményeket [26]. A rivaroxaban használatával kapcsolatban az ortopéd sebészetben a 2010-es bevezetése óta sok tapasztalatot szereztünk. Az elmúlt időszakban több vizsgálat is felhívta a figyelmet arra, hogy a közvetlen perioperatív időszakban alkalmazott LMWH-hoz hasonlítva rivaroxaban használata során nagyobb esetszámban fordulhatnak elő egyéb formában, de akár reoperációt is igénylő sebgyógyulási zavarok [27].

Tudomásunk szerint ez az első tanulmány, amely a tranexámsav hatását vizsgálja elektív cementes csípőTEP beültetéseinek esetében, tromboprofilaxisként rivaroxabant alkalmazva, ahol a vizsgálat középpontjában a perioperatív kis vérzéses szövődmények állnak.

Vizsgálatunkban a tranexámsavval kezelt betegeknél a sebvérzés mértékében szignifikáns csökkenést találtunk. Ezeknél a betegeknél kötéscserére is ritkábban volt szükség, valamint rövidebb idő alatt alakult ki a száraz mútéti seb a kontrollcsoporthoz hasonlítva. A bőr felszínén kialakuló felszínes haematoma szignifikánsan kisebb méretü lett a vizsgált csoportban a kontrollcsoporthoz viszonyítva. Egy korábbi randomizált, kettős vakvizsgálat a mútét utáni 7. napon ultrahang segítségével mérte a mély haematoma térfogatát, ahol a betegek egy része tranexámsavat kapott a csípő-TEP-beültetés során [3]. A szerzők nem találtak szignifikáns különbséget, azonban a haematoma átlagos térfogata $28 \%$-kal kisebb lett a TXA-csoportban a kontrollcsoporthoz viszonyítva (270 $\mathrm{ml}$ [CI 209-331] versus $376 \mathrm{ml}$ [CI 257-494]) [28].

Korábbi tanulmányok olyan tényezőket vizsgáltak, melyek elhúzódó sebgyógyulást és protézisbeültetést követő fertőzést okozhatnak $[29,30]$. Ezek alapján a mütét utáni haematoma és combtérfogat-növekedés későbbi fertőzéses szövődmények forrása lehet. Vizsgálatunk beteganyaga kevés ahhoz, hogy reprezentatívan következtetéseket vonhasson le olyan ritka szövődményekről, mint a protézisbeültetést követő fertőzés. Statisztikailag azonban bizonyítottan csökkent a fertőzéses szövődményekre hajlamosító tényezők előfordulási gyakorisága a tranexámsavat kapó betegek körében.

Vizsgálatunknak számos erőssége és gyengesége is van. Egyetlen, nagy esetszámmal dolgozó intézet adatait dolgozza fel, ugyanazt a mütéti technikát alkalmazva minden beteg esetében. Mindkét vizsgálati periódusban egy vizsgáló figyelte és mérte le a betegek adatait. Az összehasonlított két betegcsoport kiinduló alapadatai 
megegyeztek, illetve statisztikai következtetések levonásához elegendő számú beteget vontunk be vizsgálatunkba. A mútét körüli vérveszteséget részletesen, több szempontból is figyeltük (mútét alatti vérveszteség, drénváladék, hemoglobinkoncentráció, a sebhaematoma mérete és a sebváladékozás mértéke). A randomizáció hiánya kétség nélkül csökkentheti vizsgálatunk értékét, azonban a két vizsgált csoport időben jól elhatárolódott egymástól, és az egyetlen változó közöttük a tranexámsav alkalmazása volt.

Tanulmányunkkal kapcsolatban esetleg felmerülhet, hogy a TXA nagyobb dózisban jobb eredményt mutatott volna, eredményeinkkel összhangban azonban más vizsgálatok is kimutatták, hogy 1000 mg vagy még kisebb dózisú tranexámsav is hatásosan csökkenti a vérveszteséget és a mútétet követő transzfúziós igényt csípő- és térdprotézis-beültetést követően [31].

Vizsgálatunkban a perioperatívan alkalmazott tranexámsav kis vérzési szövődményekre kifejtett hatását figyeltük, előre jól meghatározott, cementes csípő-TEP beültetésén átesett betegcsoportban, ahol rivaroxabant alkalmaztak véralvadásgátlóként. A tranexámsav kis vérzési szövődményeket csökkentő hatását bizonyította vizsgálatunk, mely ezáltal közvetlenül csökkenti a sebgyógyulást zavaró tényezôket, így akár csökkentheti a periprotetikus fertőzések számát is. További nagy esetszámú és hosszú távú vizsgálatok szükségesek, hogy a tranexámsavnak a fertőzésekre kifejtett pozitív hatását vizsgálják.

Anyagi támogatás: A közlemény megírása anyagi támogatásban nem részesültt.

Szerzői munkamegosztás: G. Cs., S. K.: A kézirat elkészítése, megszerkesztése. G. Cs., G. H., B. M.: Adatgyújtés, irodalomkutatás. G. Cs., G. H., B. M.: Adatelemzés, statisztikai elemzés. A cikk végleges változatát valamenynyi szerző elolvasta és jóváhagyta.

Érdekeltségek: A szerzőknek a közleményhez kapcsolódó közvetlen érdekeltségeik nincsenek.

\section{Köszönetnyilvánítás}

Köszönetünket fejezzük Dr. Szalárdy Leventének, a SZTE ÁOK Neurológiai Klinika munkatársának a statisztikai elemzésekben nyújtott önzetlen segító munkájáért.

\section{Irodalom}

[1] McSwiney MM, O'Farrell D, Joshi GP, et al. Blood transfusion in total hip arthroplasty: guidelines to eliminate overtransfusion. Can J Anaesth. 1993; 40: 222-226.

[2] Ekbäck G, Axelsson K, Ryttberg L, et al. Tranexamic acid reduces blood loss in total hip replacement surgery. Anesth Analg. 2000; 91: 1124-1130.

[3] Benoni G, Fredin H, Knebel R, et al. Blood conservation with tranexamic acid in total hip arthroplasty: a randomized, double- blind study in 40 primary operations. Acta Orthop Scand. 2001; 72: 442-448.

[4] Claeys MA, Vermeersch N, Haentjens P. Reduction of blood loss with tranexamic acid in primary total hip replacement surgery. Acta Chir Belg. 2007; 107: 397-401.

[5] Sukeik M, Alshryda S, Haddad FS, et al. Systematic review and meta-analysis of the use of tranexamic acid in total hip replacement. J Bone Joint Surg Br. 2011; 93: 39-46.

[6] Johansson T, Pettersson LG, Lisander B. Tranexamic acid in total hip arthroplasty saves blood and money: a randomized, double-blind study in 100 patients. Acta Orthop. 2005; 76: 314-319.

[7] Irwin A, Khan SK, Jameson SS, et al. Oral versus intravenous tranexamic acid in enhanced-recovery primary total hip and knee replacement: results of 3000 procedures. Bone Joint J. 2013; 95-B: 1556-1561.

[8] Clavé A, Fazilleau F, Dumser D, et al. Efficacy of tranexamic acid on blood loss after primary cementless total hip replacement with rivaroxaban thromboprophylaxis: a case-control study in $70 \mathrm{pa}-$ tients. Orthop Traumatol Surg Res. 2012; 98: 484-490.

[9] Niskanen RO, Korkala OL. Tranexamic acid reduces blood loss in cemented hip arthroplasty: a randomized, double-blind study of 39 patients with osteoarthritis. Acta Orthop. 2005; 76: 829832.

[10] National Institute for Health and Clinical Excellence (NICE): Venous thromboembolism in over 16s: reducing the risk of hospital-acquired deep vein thrombosis or pulmonary embolism. Available from: https://www.nice.org.uk/guidance/ng89. [accessed: October 8, 2018].

[11] Falck-Ytter Y, Francis CW, Johanson NA, et al. Prevention of VTE in orthopedic surgery patients: Antithrombotic Therapy and Prevention of Thrombosis, 9th ed: American College of Chest Physicians Evidence-Based Clinical Practice Guidelines. Chest 2012; 141(2 Suppl): e278S-e325S.

[12] Fujisawa M, Naito M, Asayama I, et al. Effect of calf-thigh intermittent pneumatic compression device after total hip arthroplasty: comparative analysis with plantar compression on the effectiveness of reducing thrombogenesis and leg swelling. J Orthop Sci. 2003; 8: 807-811.

[13] Jones PR, Pearson J. Anthropometric determination of leg fat and muscle plus bone volumes in young male and female adults. J Physiol. 1969; 204: 63P-66P.

[14] Nadler SB, Hidalgo JH, Bloch T. Prediction of blood volume in normal human adults. Surgery 1962; 51: 224-232.

[15] Bourke DL, Smith TC. Estimating allowable hemodilution. Anesthesiology 1974; 41: 609-612.

[16] Rajesparan K, Biant LC, Ahmad M, et al. The effect of an intravenous bolus of tranexamic acid on blood loss in total hip replacement. J Bone Joint Surg Br. 2009; 91: 776-783.

[17] MacGillivray RG, Tarabichi SB, Hawari MF, et al. Tranexamic acid to reduce blood loss after bilateral total knee arthroplasty: a prospective, randomized double blind study. J Arthroplasty 2011; 26: 24-28.

[18] Lemay E, Guay J, Côté C, et al. Tranexamic acid reduces the need for allogenic red blood cell transfusions in patients undergoing total hip replacement. Can J Anaesth. 2004; 51: 31-37.

[19] Levine BR, Haughom BD, Belkin MN, et al. Weighted versus uniform dose of tranexamic acid in patients undergoing primary, elective knee arthroplasty: a prospective randomized controlled trial. J Arthroplasty 2014; 29(9 Suppl): 186-188.

[20] Imai N, Dohmae $Y$, Suda K, et al. Tranexamic acid for reduction of blood loss during total hip arthroplasty. J Arthroplasty 2012; 27: 1838-1843.

[21] de Jonge T, Görgényi Sz, Szabó G, et al. Local infiltration analgesia in total joint replacement. [Helyi infiltrációs érzéstelenítés alkalmazása nagyízületi endoprotézisek beültetése során.] Orv Hetil. 2017; 158: 352-357. [Hungarian] 
[22] Wong J, Abrishami A, El Beheiry H, et al. Topical application of tranexamic acid reduces postoperative blood loss in total knee arthroplasty: a randomized, controlled trial. J Bone Joint Surg Am. 2010; 92: 2503-2513.

[23] Yamasaki S, Masuhara K, Fuji T. Tranexamic acid reduces blood loss after cementless total hip arthroplasty - prospective randomized study in 40 cases. Int Orthop. 2004; 28: 69-73.

[24] Ido K, Neo M, Asada Y, et al. Reduction of blood loss using tranexamic acid in total knee and hip arthroplasties. Arch Orthop Trauma Surg. 2000; 120: 518-520.

[25] Bereczky Zs, Oláh Zs, Ajzner É, et al. Laboratory aspects of novel oral anticoagulant treatment. [Az új orális antikoagulánsokkal történő kezelés laboratóriumi vonatkozásai.] Orv Hetil. 2017; 158: 1930-1945. [Hungarian]

[26] Keltai M, Keltai K. New anticoagulants in the prevention and treatment of venous thromboembolism. [Új antikoagulánsok a vénás thromboembolia megelőzésében és kezelésében.] Orv Hetil. 2011; 152: 983-992. [Hungarian]

[27] Jensen CD, Steval A, Partington PF, et al. Return to theatre following total hip and knee replacement, before and after the in- troduction of rivaroxaban: a retrospective cohort study. J Bone Joint Surg Br. 2011; 93: 91-95.

[28] Krishnamurti C, Vukelja SJ, Alving BM. Inhibitory effects of lysine analogues on t-PA induced whole blood clot lysis. Thromb Res. 1994; 73: 419-430.

[29] Freeman MA, Challis JH, Zelezonski J, et al. Sepsis rates in hip replacement surgery with special reference to the use of ultra clean air. Arch Orthop Unfallchir. 1977; 90: 1-14.

[30] Wilson PD Jr. Joint replacement. South Med J. 1977; 70(Suppl 1): 55-60.

[31] Poeran J, Rasul R, Suzuki S, et al. Tranexamic acid use and postoperative outcomes in patients undergoing total hip or knee arthroplasty in the United States: retrospective analysis of effectiveness and safety. BMJ 2014; 349: g4829.

(Gombár Csaba dr., Szeged, Semmelweis u. 6., 6725 e-mail: csaba.gombar@yahoo.co.uk)

\section{MEGHÍVó}

\section{A Szent János Kórház és Észak-budai Egyesített Kórházak Tudományos Bizottsága} tisztelettel meghívja az érdeklődőket a következő tudományos ülésére.

Időpont: 2019. március 28. (csütörtök) 14 óra

Helyszín: Szent János Kórház Auditóriuma - 1125 Budapest, Diós árok 1-3.

Téma: Az időskorú betegek ellátásának speciális kérdései II.

Üléselnök: Prof. Dr. Jánosi András

\section{Program:}

Prof. Dr. Józan Péter, Dr. Lukovich Péter:

Az idősödő társadalom és ennek sebészeti vonatkozásai 20 perc

Dr. Nyulasi Tibor:

Idős betegek az Intenzív Osztályon, mennyire legyünk invazívak a kezelésben 20 perc

Dr. Merényi Gábor, Dr. Tóközi Péter, Dr. Pál Simon:

Idős sérültek traumatológiai ellátási problémái 20 perc

Dr. Gombos Katalin: Az idősödő szem 20 perc

Minden érdeklődőt szeretettel várunk.

A cikk a Creative Commons Attribution 4.0 International License (https://creativecommons.org/licenses/by/4.0/) feltételei szerint publikált Open Access közlemény, melynek szellemében a cikk bármilyen médiumban szabadon felhasználható, megosztható és újraközölhetö, feltéve, hogy az eredeti szerző és a közlés helye, illetve a CC License linkje és az esetlegesen végrehajtott módosítások feltüntetésre kerülnek. (SID_1) 